Bull. Chem. Soc. Ethiop. 2012, 26(2), 239-247.

Printed in Ethiopia

ISSN 1011-3924

DOI: http://dx.doi.org/10.4314/bcse.v26i2.7

(c) 2012 Chemical Society of Ethiopia

\title{
SPECIATION OF L-ASPARTIC ACID COMPLEXES OF Co(II), Ni(II), Cu(II) AND Zn(II) IN ACETONITRILE- AND ETHYLENE GLYCOL-WATER MIXTURES
}

\author{
Nethala Vijaya Kumar, Bathula Sreekanth and Gollapalli Nageswara Rao* \\ School of Chemistry, Andhra University, Visakhapatnam-530003, India
}

(Received January 3, 2011; revised March 6, 2012)

\begin{abstract}
Chemical speciation of binary complexes of $\mathrm{Co}$ (II), $\mathrm{Ni}$ (II), $\mathrm{Cu}$ (II) and $\mathrm{Zn}$ (II) with $\mathrm{L}$-aspartic acid was investigated $\mathrm{pH}$-metrically in acetonitrile- and ethylene glycol-water mixtures. The stability constants were calculated using the computer program MINIQUAD75. The best-fit chemical models were selected based on statistical parameters and residual analysis. The models for the binary species contained $\mathrm{ML}_{2} \mathrm{H}_{2}, \mathrm{ML}_{2} \mathrm{H}_{\text {and }} \mathrm{ML}_{2}$ for $\mathrm{Co}$ (II) and $\mathrm{Zn}$ (II), ML, $\mathrm{ML}_{2} \mathrm{H}_{2}$ and $\mathrm{ML}_{2}$ for $\mathrm{Ni}$ (II) and $\mathrm{Cu}$ (II) in acetonitrile- and ethylene glycol-water mixtures. The trend in variation of stability constants with change in the dielectric constant of the medium was explained on the basis of electrostatic and non-electrostatic forces. Distribution of the species with $\mathrm{pH}$ at different variations $(0.0-60.0 \% \mathrm{v} / \mathrm{v})$ in acetonitrile- and ethylene glycol-water mixtures was also presented.
\end{abstract}

KEY WORDS: Complex equilibria, L-Aspartic acid, Acetonitrile, Ethylene glycol, MINIQUAD75

\section{INTRODUCTION}

A number of studies have been reported on chemical speciation of $\alpha$-amino acids in different media in recent times [1-3]. Chemical speciation of a molecule is governed by its structure and solvent effects $[4,5]$. L-aspartic acid is a non-essential amino acid found in abundance in plant proteins. It plays an important role in maintaining the solubility and ionic character of proteins [6]. It assists the liver in removing excess ammonia and other toxins from the blood stream. It is also very important in the functioning of RNA and DNA, in immunoglobulin and antibody synthesis. Asp is popular as a drug for chronic fatigue as it plays crucial role in generating cellular energy, moves the coenzyme nicotinamide adenine dinucleotide molecules from the main body of the cell to its mitochondria, where it is used to generate adenosine triphosphate (ATP) [7].

Cobalt is essential for the production of the red blood cells and cobalamin acts as the substrate for the final enzymatic reaction that yields the active coenzyme derivatives of cyanocobalamin and aquacobalamin. Nickel is found in enzymes, such as urease, which is a dinuclear Ni(II)-containing metalloenzyme [8-10]. This enzyme catalyses the hydrolysis of urea to yield ammonia and carbamate. The copper-containing enzymes and proteins constitute an important class of biologically active compounds. The biological functions include electron transfer, dioxygen transport, oxygenation, oxidation, reduction and disproportionation [11, 12]. Zinc plays either a predominantly catalytic role or solely a structural role to maintain the protein configuration. It is a versatile ion as it can bind to different combinations of ligand types resulting in a broad range of stability, reactivity and functions [13].

The aim of the present study is to understand the role of metal ions at active site cavities in bioactive molecules like enzymes and proteins to know the effect of dielectric constant of the medium on the chemical speciation of the binary complexes of $\mathrm{Co}$ (II), $\mathrm{Ni}$ (II), $\mathrm{Cu}$ (II) and $\mathrm{Zn}$ (II) with L-aspartic acid (Asp). Asp has been taken as a model compound for amino acid residues. Since the dielectric constant at the active site cavities is very small compared to that at biofluids, low dielectric constant is mimicked by using a water soluble organic solvent like acetonitrile (AN) and ethylene glycol (EG). AN is a protophobic dipolar aprotic solvent and it

*Corresponding author. E-mail: gollapallinr@yahoo.com 
does not form any hydrogen bond with solute species. The protophobic character of AN may arise from the possible formation of dimers which are shown to exist from IR studies [14]. EG is a protophilic dipolar protic solvent and acts as a structure former. Having two hydroxyl groups EG is distinctly different from monohydric alcohols. It is more acidic than water $[15,16]$ due to electron withdrawing effect [17] of $\mathrm{CH}_{2}$ group. Very few studies have been reported in the literature on effect of dielectric constants in organic solvent- water mixtures [18-20]. Hence, speciation studies of the title systems have been undertaken based on their involvement in various physiological reactions.

Material

\section{EXPERIMENTAL}

$0.05 \mathrm{M}$ solution of L-aspartic acid (GR, E-Merck, Germany) was prepared in triple distilled water. $0.1 \mathrm{M}$ solutions of $\mathrm{Co}(\mathrm{II}), \mathrm{Ni}(\mathrm{II}), \mathrm{Cu}$ (II) and $\mathrm{Zn}$ (II) nitrates (GR, E-Merck, Germany) were prepared by maintaining $0.05 \mathrm{M}$ acid $\left(\mathrm{HNO}_{3}\right)$ concentration to suppress the hydrolysis. Acetonitrile (GR, E-Merck) and ethylene glycol (AR, Qualigen) were used as received. $2.0 \mathrm{M}$ sodium nitrate solution was prepared to maintain ionic strength in the titrand. Sodium hydroxide of $0.4 \mathrm{M}$ was prepared. The strengths of alkali and mineral acid were determined using the Gran plot method [21, 22].

\section{Apparatus}

The alkalimetric titration data were obtained by using calibrated ELICO (Model LI-120, India.) $\mathrm{pH}$-meter. The glass electrode was equilibrated in well stirred acetonitrile- or ethylene glycolwater mixture solutions containing inert electrolyte $\left(\mathrm{NaNO}_{3}\right)$. The effects of variations in asymmetry, liquid junction potential, activity coefficient, sodium ion error and dissolved carbon dioxide on the response of glass electrode were accounted for in the form of correction factor. For the determination of stability constants of metal-ligand binary species, initially titrations of strong acid with alkali were carried out at regular intervals to check whether complete equilibration was achieved.

\section{Procedure}

All the titrations have been carried out in the medium containing varying concentrations of ANand EG-water mixtures $(0.0-60.0 \% \mathrm{v} / \mathrm{v})$ maintaining an ionic strength of $0.16 \mathrm{M}$ with sodium nitrate at $303.0 \mathrm{~K}$. In each of the titrations, the titrand consisted of approximately $1 \mathrm{mmol}$ mineral acid in a total volume of $50 \mathrm{~mL}$. Titrations with different ratios (1:2.5, 1:3.5, 1:5.0) of metal-to-ligand were carried out with $0.4 \mathrm{M}$ sodium hydroxide. Other experimental details are given elsewhere [23].

\section{Modeling strategy}

The computer program SCPHD [24] was used to calculate the correction factor. The binary stability constants were calculated from the $\mathrm{pH}$-metric titration data with the computer program MINIQUAD75 [25] which exploits the advantage of constrained least-squares method and reliable convergence of Marquardt algorithm. During the refinement of binary systems, the correction factor and the protonation constants of Asp were fixed. The variation of stability constants with the dielectric constants of AN- and EG-water mixtures were analyzed on electrostatic, non-electrostatic, solute-solute and solute-solvent interactions. 


\section{RESULTS AND DISCUSSION}

The results of the best fit models that contain the stoichiometry of the complex species and their overall formation constants are given in Tables 1 and 2. A very low standard deviation in $\log \beta$ values indicates the precision of these parameters. The small values of $U_{\text {corr }}$ (sum of squares of deviations in concentrations of ingredients at all experimental points corrected for degrees of freedom) indicate that the experimental data can be represented by the model. Small values of mean, standard deviation and mean deviation for the systems corroborate that the residuals are around a zero mean with little dispersion. For an ideal normal distribution, the values of kurtosis and skewness should be three and zero, respectively. The kurtosis values in the present study indicate that the residuals form leptokurtic as well as platykurtic patterns and very few form mesokurtic patterns [26]. The skewness values are between -0.01 and 3.89.

Table 1. Parameters of best fit chemical models of Asp complexes of $\mathrm{Co}(\mathrm{II}), \mathrm{Ni}(\mathrm{II}), \mathrm{Cu}$ (II) and $\mathrm{Zn}$ (II) in AN-water mixtures.

\begin{tabular}{|c|c|c|c|c|c|c|c|c|c|c|}
\hline \multirow{2}{*}{$\begin{array}{c}\% \mathrm{v} / \mathrm{v} \\
\mathrm{AN}\end{array}$} & \multicolumn{4}{|c|}{$\log \beta_{\mathrm{mlh}}(\mathrm{SD})$} & \multirow[b]{2}{*}{ NP } & \multirow[t]{2}{*}{$\mathrm{U}_{\text {corr }}$} & \multirow{2}{*}{$\begin{array}{c}\text { Skew- } \\
\text { ness }\end{array}$} & \multirow[t]{2}{*}{ Kurtosis } & \multirow[t]{2}{*}{$\chi^{2}$} & \multirow[t]{2}{*}{ R-factor } \\
\hline & 110 & 120 & 121 & 122 & & & & & & \\
\hline \multicolumn{11}{|c|}{$\mathrm{Co}(\mathrm{pH}=4.9-9.0)$} \\
\hline 0.0 & -- & $10.83(4)$ & $18.56(4)$ & $24.44(10)$ & 29 & 3.17 & 0.06 & 3.42 & 2.93 & 0.0172 \\
\hline 10.0 & -- & $10.82(4)$ & 18.11(4) & $24.94(6)$ & 33 & 3.86 & 0.50 & 4.25 & 47.02 & 0.0548 \\
\hline 20.0 & -- & $11.36(3)$ & $18.76(3)$ & $24.39(9)$ & 29 & 3.84 & 0.04 & 5.09 & 11.07 & 0.0190 \\
\hline 30.0 & -- & $11.33(3)$ & $18.08(3)$ & $24.92(5)$ & 29 & 5.41 & 0.18 & 6.27 & 10.51 & 0.0220 \\
\hline 40.0 & -- & $11.27(4)$ & $18.24(6)$ & $24.37(9)$ & 25 & 4.46 & 0.27 & 5.61 & 35.40 & 0.0601 \\
\hline 50.0 & -- & $12.27(3)$ & $18.92(3)$ & $24.24(6)$ & 28 & 4.86 & 0.31 & 3.92 & 8.52 & 0.0364 \\
\hline 60.0 & -- & $12.07(3)$ & 18.97(3) & $24.51(8)$ & 28 & 5.13 & 0.08 & 4.74 & 7.33 & 0.0301 \\
\hline \multicolumn{11}{|c|}{$\mathrm{Ni}(\mathrm{pH}=4.1-8.9)$} \\
\hline 0.0 & $7.01(5)$ & $12.26(7)$ & -- & $23.74(12)$ & 25 & 0.55 & -0.21 & 5.88 & 7.03 & 0.0069 \\
\hline 10.0 & $7.15(2)$ & $12.76(7)$ & -- & $23.95(7)$ & 23 & 5.85 & 0.20 & 2.24 & 2.07 & 0.0228 \\
\hline 20.0 & $7.45(6)$ & $13.30(7)$ & -- & $24.90(7)$ & 21 & 2.01 & 0.36 & 5.05 & 10.27 & 0.0139 \\
\hline 30.0 & $7.76(5)$ & $13.48(6)$ & -- & $24.79(6)$ & 24 & 0.26 & -0.33 & 2.15 & 11.71 & 0.0049 \\
\hline 40.0 & $7.67(8)$ & $13.69(8)$ & -- & $24.94(12)$ & 25 & 0.95 & -0.26 & 2.26 & 4.24 & 0.0098 \\
\hline 50.0 & $7.71(2)$ & $13.47(4)$ & -- & $24.85(6)$ & 26 & 0.80 & 0.07 & 4.46 & 4.33 & 0.0085 \\
\hline 60.0 & $8.68(8)$ & $14.70(8)$ & -- & $25.95(11)$ & 27 & 0.98 & -0.20 & 2.23 & 4.28 & 0.0098 \\
\hline \multicolumn{11}{|c|}{$\mathrm{Cu}(\mathrm{pH}=3.1-9.0)$} \\
\hline 0.0 & $8.37(2)$ & $15.09(4)$ & -- & $24.31(6)$ & 41 & 0.33 & 0.02 & 5.69 & 14.30 & 0.0046 \\
\hline 10.0 & $8.12(2)$ & $15.42(2)$ & -- & $24.37(5)$ & 28 & 2.94 & 0.40 & 3.73 & 10.86 & 0.0158 \\
\hline 20.0 & $7.82(2)$ & $14.81(2)$ & -- & $24.27(5)$ & 28 & 4.20 & 0.34 & 3.36 & 2.48 & 0.0189 \\
\hline 30.0 & $8.34(5)$ & $15.51(7)$ & -- & $25.84(7)$ & 22 & 6.36 & 0.29 & 6.20 & 7.45 & 0.0232 \\
\hline 40.0 & $9.12(6)$ & $16.49(6)$ & -- & $26.16(8)$ & 20 & 0.80 & 1.02 & 5.21 & 8.53 & 0.0086 \\
\hline 50.0 & $8.91(6)$ & $16.12(6)$ & -- & $26.23(7)$ & 23 & 2.15 & 0.29 & 4.39 & 7.87 & 0.0140 \\
\hline 60.0 & $8.96(8)$ & $15.99(8)$ & -- & $26.37(10)$ & 28 & 2.28 & -0.62 & 4.48 & 2.89 & 0.0142 \\
\hline \multicolumn{11}{|c|}{$\mathrm{Zn}(\mathrm{pH}=4.5-9.4)$} \\
\hline 0.0 & -- & $10.37(4)$ & $18.31(4)$ & $24.50(10)$ & 23 & 2.99 & 0.22 & 4.85 & 7.87 & 0.0173 \\
\hline 10.0 & -- & $10.46(2)$ & $17.84(2)$ & $24.53(6)$ & 28 & 7.88 & 0.29 & 6.96 & 50.86 & 0.0275 \\
\hline 20.0 & -- & $10.55(2)$ & $17.60(3)$ & $24.58(7)$ & 30 & 8.03 & 0.24 & 6.27 & 34.98 & 0.0457 \\
\hline 30.0 & -- & $10.67(2)$ & $17.52(4)$ & $24.65(8)$ & 28 & 8.12 & 0.27 & 6.70 & 59.24 & 0.0490 \\
\hline 40.0 & -- & $11.23(8)$ & $17.36(8)$ & $24.40(12)$ & 27 & 9.04 & 0.21 & 5.39 & 25.77 & 0.0539 \\
\hline 50.0 & -- & $11.28(6)$ & $17.39(6)$ & $24.51(10)$ & 25 & 8.77 & 0.23 & 5.02 & 24.52 & 0.0555 \\
\hline 60.0 & -- & $11.39(6)$ & $17.14(6)$ & $24.43(11)$ & 34 & 9.98 & 0.25 & 5.40 & 44.67 & 0.0909 \\
\hline
\end{tabular}


Table 2. Parameters of best fit chemical models of Asp complexes of $\mathrm{Co}(\mathrm{II}), \mathrm{Ni}(\mathrm{II}), \mathrm{Cu}(\mathrm{II})$ and $\mathrm{Zn}$ (II) in EG-water mixtures.

\begin{tabular}{|c|c|c|c|c|c|c|c|c|c|c|}
\hline \multirow[b]{2}{*}{$\begin{array}{l}\% \mathrm{v} / \mathrm{v} \\
\text { EG }\end{array}$} & \multicolumn{4}{|c|}{$\log \beta_{\mathrm{mlh}}(\mathrm{SD})$} & \multirow[b]{2}{*}{ NP } & \multirow[b]{2}{*}{$\mathrm{U}_{\text {corr }}$} & \multirow[b]{2}{*}{$\begin{array}{c}\text { Skewnes } \\
\mathrm{s}\end{array}$} & \multirow[b]{2}{*}{ Kurtosis } & \multirow[b]{2}{*}{$\chi^{2}$} & \multirow[b]{2}{*}{$\mathrm{R}$-factor } \\
\hline & 110 & 120 & 121 & 122 & & & & & & \\
\hline \multicolumn{11}{|c|}{$\mathrm{Co}(\mathrm{pH}=4.5-9.4)$} \\
\hline 10.0 & -- & $11.39(3)$ & $18.80(3)$ & $24.53(5)$ & 20 & 2.21 & 0.60 & 4.09 & 5.87 & 0.0146 \\
\hline 20.0 & -- & $11.37(2)$ & 18.62(3) & $24.00(10)$ & 20 & 1.98 & 0.03 & 3.56 & 17.33 & 0.0136 \\
\hline 30.0 & -- & $11.59(3)$ & $18.32(4)$ & $24.92(11)$ & 24 & 8.00 & 0.32 & 7.93 & 22.44 & 0.0273 \\
\hline 40.0 & -- & $12.08(4)$ & $18.86(5)$ & $24.34(12)$ & 24 & 6.42 & 0.31 & 7.29 & 10.67 & 0.0246 \\
\hline 50.0 & -- & $12.14(2)$ & $18.74(9)$ & $24.81(12)$ & 30 & 7.11 & 0.42 & 5.10 & 5.10 & 0.0403 \\
\hline 60.0 & -- & $12.90(3)$ & 19.37(4) & $24.90(8)$ & 28 & 2.20 & 0.40 & 4.51 & 16.95 & 0.0358 \\
\hline \multicolumn{11}{|c|}{$\mathrm{Ni}(\mathrm{pH}=4.1-9.0)$} \\
\hline 10.0 & $7.33(2)$ & $13.25(6)$ & -- & $24.37(8)$ & 21 & 0.65 & 1.44 & 6.20 & 8.49 & 0.0079 \\
\hline 20.0 & $7.23(2)$ & $13.12(4)$ & -- & $24.00(6)$ & 21 & 0.88 & 1.70 & 6.86 & 17.13 & 0.0093 \\
\hline 30.0 & $7.35(3)$ & 13.14(4) & -- & $24.07(6)$ & 27 & 0.68 & 0.19 & 4.01 & 3.43 & 0.0079 \\
\hline 40.0 & $7.45(4)$ & $13.36(5)$ & -- & $24.11(8)$ & 27 & 0.75 & 0.43 & 3.38 & 1.55 & 0.0083 \\
\hline 50.0 & $7.49(2)$ & $13.53(2)$ & -- & $24.35(4)$ & 21 & 1.64 & 0.78 & 3.11 & 4.17 & 0.0128 \\
\hline 60.0 & $7.44(2)$ & $13.51(2)$ & -- & $24.36(5)$ & 22 & 2.35 & 0.46 & 5.31 & 6.21 & 0.0150 \\
\hline \multicolumn{11}{|c|}{$\mathrm{Cu}(\mathrm{pH}=2.9-8.7)$} \\
\hline 10.0 & $8.75(2)$ & $16.07(4)$ & -- & $24.74(12)$ & 41 & 0.54 & -0.37 & 4.27 & 11.70 & 0.0059 \\
\hline 20.0 & $8.84(2)$ & $16.27(4)$ & -- & $24.82(8)$ & 40 & 0.55 & -0.35 & 4.07 & 12.27 & 0.0059 \\
\hline 30.0 & $8.15(6)$ & $15.23(11)$ & -- & $24.29(11)$ & 42 & 2.08 & -0.29 & 3.55 & 10.00 & 0.0115 \\
\hline 40.0 & $8.24(6)$ & $15.43(10)$ & -- & $24.47(10)$ & 42 & 2.09 & -0.29 & 3.40 & 7.46 & 0.0116 \\
\hline 50.0 & $8.01(5)$ & $15.21(12)$ & -- & $24.28(12)$ & 35 & 0.53 & 0.10 & 2.73 & 24.14 & 0.0274 \\
\hline 60.0 & $8.24(2)$ & $16.15(4)$ & -- & $24.79(10)$ & 47 & 3.00 & -0.01 & 3.49 & 5.10 & 0.0129 \\
\hline \multicolumn{11}{|c|}{$\mathrm{Zn}(\mathrm{pH}=4.5-9.5)$} \\
\hline 10.0 & -- & $11.00(2)$ & $18.70(2)$ & $24.34(5)$ & 30 & 7.40 & 2.20 & 8.82 & 40.49 & 0.0284 \\
\hline 20.0 & -- & $11.14(2)$ & $18.78(3)$ & $24.25(5)$ & 30 & 8.55 & 2.00 & 7.42 & 24.49 & 0.0305 \\
\hline 30.0 & -- & $11.44(2)$ & $18.54(2)$ & $23.96(6)$ & 30 & 7.29 & 1.71 & 6.21 & 28.04 & 0.0280 \\
\hline 40.0 & -- & $11.36(5)$ & $18.69(9)$ & $24.08(12)$ & 28 & 5.85 & 0.82 & 5.10 & 30.29 & 0.0245 \\
\hline 50.0 & -- & $11.72(2)$ & $18.07(2)$ & $23.72(5)$ & 28 & 6.60 & 0.61 & 3.77 & 13.14 & 0.0406 \\
\hline 60.0 & -- & $11.75(2)$ & $17.96(3)$ & $23.66(10)$ & 27 & 7.82 & 3.89 & 3.89 & 11.94 & 0.0447 \\
\hline
\end{tabular}

These data evidence that the residuals form a part of normal distribution. Hence, least squares method can be applied to the present data. The sufficiency of the model is further evident from the low crystallographic R-values. These statistical parameters thus show that the best fit models portray the metal-ligand species in AN- and EG-water mixtures.

\section{Incorporation of errors}

In order to rely upon the best chemical model for critical evaluation and application under varied experimental conditions with different accuracies of data acquisition, an investigation was made by introducing pessimistic errors in the influential parameters like concentrations of alkali, mineral acid, ligand and metal. The order of the ingredients that influence the magnitudes of stability constants due to incorporation of errors is alkali $>$ acid $>$ ligand $>$ metal (Table 3 ). Some of the species refined in the absence of errors were even rejected when errors were introduced in the concentrations. One or more of $\mathrm{ML}_{2}, \mathrm{ML}_{2} \mathrm{H}$ and $\mathrm{ML}_{2} \mathrm{H}_{2}$ species were rejected depending upon the magnitude of error as given in Table 3. The rejection of species and increased standard deviations in the stability constants on introduction of errors confirm the appropriateness or correctness of the experimental conditions (concentrations of ingredients) and the choice of the best fit models. 
Table 3. Effect of errors in influential parameters on the stability constants of Co(II)-Asp complexes in $30 \% \mathrm{v} / \mathrm{v}$ of $\mathrm{AN}$ - and EG-water mixtures.

\begin{tabular}{|c|c|c|c|c|}
\hline \multirow{2}{*}{ Ingredient } & \multirow{2}{*}{$\%$ Error } & \multicolumn{3}{|c|}{$\log \beta(\mathrm{SD})$} \\
\hline & & $\mathrm{ML}_{2}$ & $\mathrm{ML}_{2} \mathrm{H}$ & $\mathrm{ML}_{2} \mathrm{H}_{2}$ \\
\hline \multicolumn{5}{|c|}{ AN } \\
\hline & 0 & $11.33(3)$ & $18.08(3)$ & $24.92(5)$ \\
\hline \multirow{4}{*}{ Alkali } & -5 & Rejected & $16.57(27)$ & $28.41(59)$ \\
\hline & -2 & $9.77(16)$ & $17.50(19)$ & $25.89(28)$ \\
\hline & +2 & Rejected & Rejected & $23.76(18)$ \\
\hline & +5 & Rejected & Rejected & Rejected \\
\hline \multirow{4}{*}{ Acid } & -5 & Rejected & Rejected & Rejected \\
\hline & -2 & Rejected & Rejected & $24.14(10)$ \\
\hline & +2 & $10.17(14)$ & $17.63(24)$ & $25.62(28)$ \\
\hline & +5 & $8.55(27)$ & $16.98(27)$ & $27.03(33)$ \\
\hline \multirow{4}{*}{ Ligand } & -5 & $12.34(3)$ & $18.19(3)$ & $24.39(8)$ \\
\hline & -2 & $11.94(2)$ & 18.024) & $24.73(6)$ \\
\hline & +2 & $10.92(3)$ & 17.97(3) & 25.11(7) \\
\hline & +5 & $10.46(3)$ & 17.74(4) & $25.39(9)$ \\
\hline \multirow{4}{*}{ Metal } & -5 & $11.90(2)$ & $17.67(7)$ & $24.88(6)$ \\
\hline & -2 & $11.60(2)$ & $17.96(4)$ & $24.90(7)$ \\
\hline & +2 & $11.20(3)$ & 18.11(2) & $24.94(6)$ \\
\hline & +5 & $11.06(3)$ & $18.12(2)$ & $24.97(6)$ \\
\hline \multicolumn{5}{|c|}{ EG } \\
\hline & 0 & $11.59(3)$ & $18.32(4)$ & $24.92(11)$ \\
\hline \multirow{4}{*}{ Alkali } & -5 & $7.83(7)$ & $16.69(6)$ & $27.73(55)$ \\
\hline & -2 & $10.14(3)$ & $17.64(3)$ & $25.79(37)$ \\
\hline & +2 & Rejected & Rejected & $23.94(64)$ \\
\hline & +5 & Rejected & Rejected & Rejected \\
\hline \multirow{4}{*}{ Acid } & -5 & Rejected & Rejected & Rejected \\
\hline & -2 & Rejected & Rejected & $24.22(43)$ \\
\hline & +2 & $10.52(2)$ & $17.76(3)$ & $25.56(34)$ \\
\hline & +5 & $8.85(5)$ & $17.12(5)$ & $26.71(51)$ \\
\hline \multirow{4}{*}{ Ligand } & -5 & $13.07(6)$ & $19.66(7)$ & $24.43(31)$ \\
\hline & -2 & $12.07(4)$ & $18.79(5)$ & $24.74(25)$ \\
\hline & +2 & $11.28(2)$ & $18.07(2)$ & $25.10(28)$ \\
\hline & +5 & $10.86(2)$ & $17.85(2)$ & $25.35(31)$ \\
\hline \multirow{4}{*}{ Metal } & -5 & $11.72(1)$ & $18.19(2)$ & $24.88(29)$ \\
\hline & -2 & $11.62(2)$ & $18.23(4)$ & $24.90(26)$ \\
\hline & +2 & $11.57(3)$ & $18.39(4)$ & $24.94(24)$ \\
\hline & +5 & $11.53(3)$ & $18.49(4)$ & $24.96(25)$ \\
\hline
\end{tabular}

\section{Solvent effect}

Effect of solvent on stability constant of chemical speciation depends upon electrostatic and non-electrostatic factors. Born's classical treatment holds good in accounting for the electrostatic contribution [27] which is related to dielectric constant. Hence, the logarithm of overall stability constants $(\log \beta)$ should vary linearly as a function of the reciprocal of dielectric constant (1/D) of the medium. The linear variation (Figure 1) indicates that electrostatic forces are dominating the non-electrostatic forces $[28,29]$ in the equilibrium process under the present experimental conditions. A perusal in to the trend of stabilities of complexes in AN and EG media (Figure 1) indicates that the slope is less in EG medium than in AN medium and 
sometimes the slope is negative. May be this is due to the more acidic nature of EG than that of $\mathrm{AN}$, since the complexation equilibria are influenced by the $\mathrm{pH}$ of the medium.
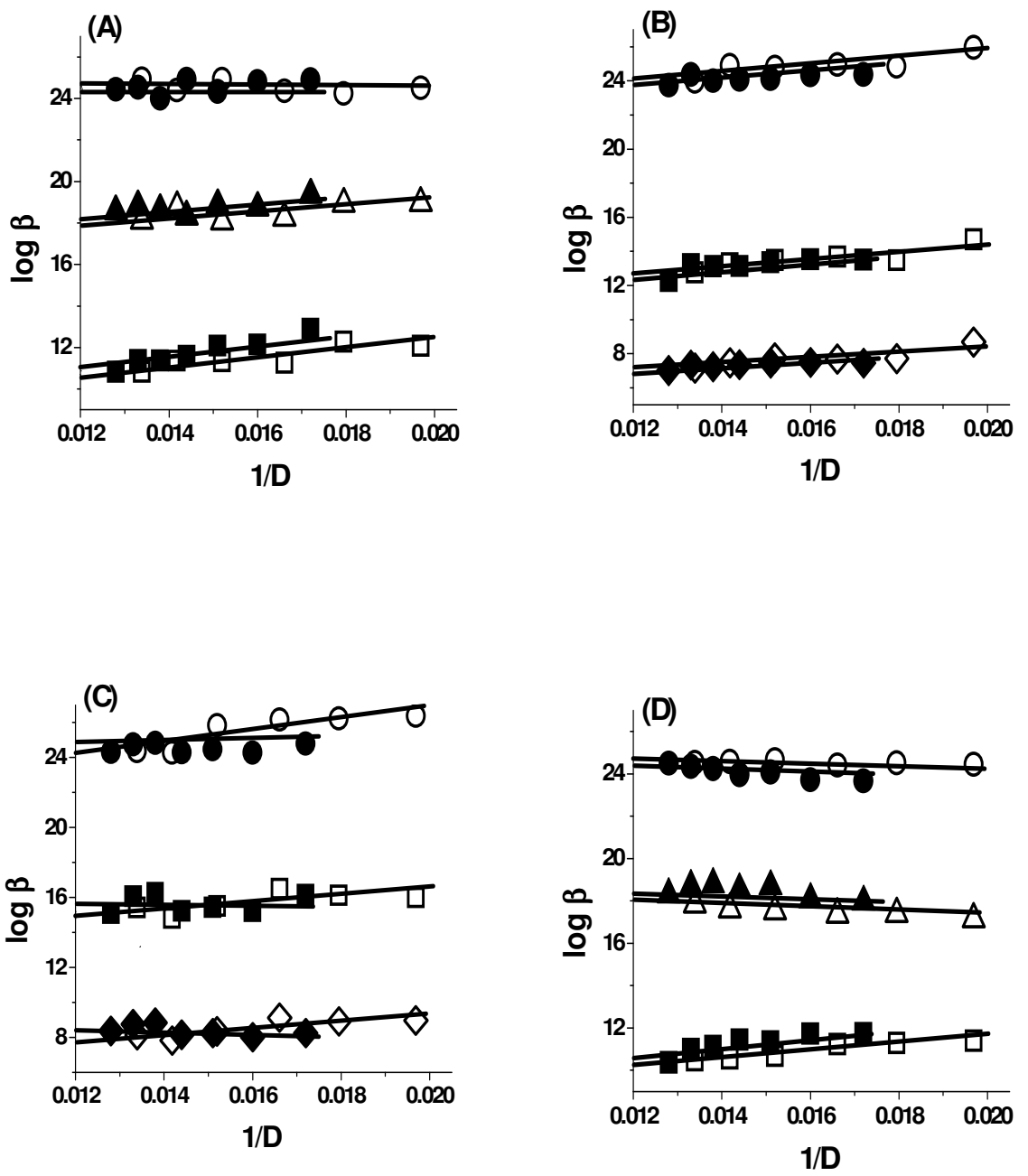

Figure 1. Variation of stability constants of metal-Asp complexes with $1 / \mathrm{D}$ of $\mathrm{AN}$ - (hallow symbols) and EG- (solid symbols) water mixtures. (A) $\mathrm{Co}$ (II), (B) $\mathrm{Ni}(\mathrm{II}),(\mathrm{C}) \mathrm{Cu}$ (II)

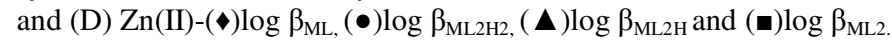

Distribution diagrams

Asp exists as $\mathrm{LH}_{3}{ }^{+}, \mathrm{LH}_{2}, \mathrm{LH}^{-}$and $\mathrm{L}^{2-}$ in the $\mathrm{pH}$-ranges 2.5-4.5, 2.5-5.5, 5.5-8.5 and 7.5-10.5, respectively. The binary metal complexes refined are $\mathrm{ML}_{2} \mathrm{H}_{2}, \mathrm{ML}_{2} \mathrm{H}$ and $\mathrm{ML}_{2}$ for $\mathrm{Co}$ (II) and $\mathrm{Zn}$ (II), ML, $\mathrm{ML}_{2} \mathrm{H}_{2}$ and $\mathrm{ML}_{2}$ for $\mathrm{Ni}$ (II) and $\mathrm{Cu}$ (II) in $\mathrm{AN}$ - and EG-water mixtures. The formations of various binary complex species are shown in the following equilibria: 


$$
\begin{array}{lll}
\mathrm{M}(\mathrm{II})+2 \mathrm{LH}_{2} & \rightleftharpoons & \mathrm{ML}_{2} \mathrm{H}_{2}+2 \mathrm{H}^{+} \\
\mathrm{ML}_{2} \mathrm{H}_{2} & \rightleftharpoons & \mathrm{ML}_{2} \mathrm{H}+\mathrm{H}^{+} \\
\mathrm{ML}_{2} \mathrm{H} & \mathrm{ML}_{2}+\mathrm{H}^{+} \\
\mathrm{M}(\mathrm{II})+\mathrm{LH}_{3} & \rightleftharpoons & \mathrm{MLH}+2 \mathrm{H}^{+} \\
\mathrm{M}(\mathrm{II})+\mathrm{LH}_{2} & \rightleftharpoons & \mathrm{MLH}+\mathrm{H}^{+} \\
\mathrm{MLH} & \rightleftharpoons & \mathrm{ML}+\mathrm{H}^{+} \\
\mathrm{ML}+\mathrm{LH} & \rightleftharpoons & \mathrm{ML}_{2}+\mathrm{H}^{+}
\end{array}
$$
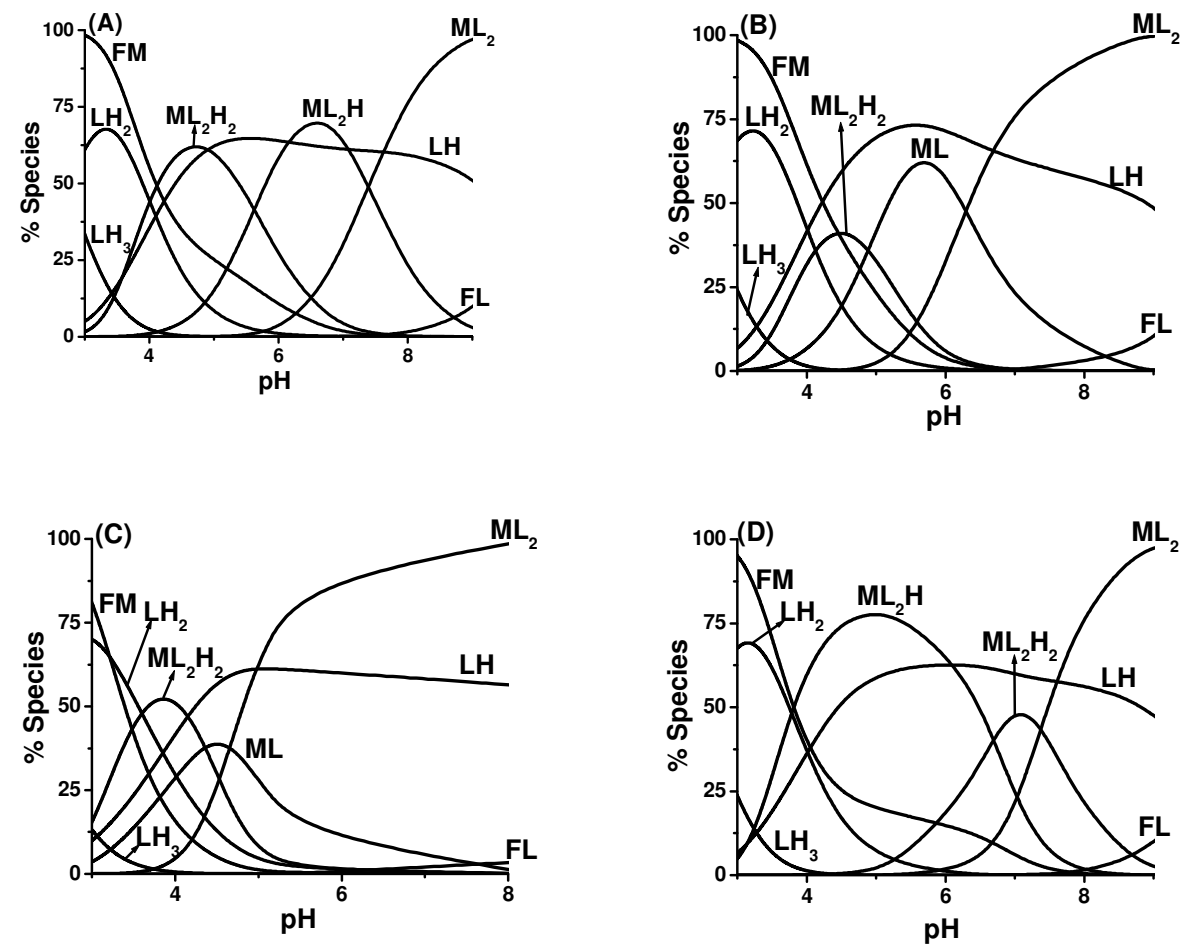

Figure 2. Species distribution diagrams of Asp complexes of (A) $\mathrm{Co}$ (II), (B) $\mathrm{Ni}$ (II), (C) $\mathrm{Cu}$ (II) and (D) $\mathrm{Zn}$ (II) in $20 \% \mathrm{v} / \mathrm{v}$, AN-water mixtures. FM and FL are the free metal and the most deprotonated form of the ligand, respectively.

Typical species distribution diagrams are shown in Figure 2, which indicate that the percentages of $\mathrm{ML}_{2} \mathrm{H}$ and $\mathrm{ML}_{2}$ species of $\mathrm{Co}(\mathrm{II})$ and $\mathrm{Zn}(\mathrm{II})$ are formed to an extent of $70-90 \%$ (Figures $2 \mathrm{~A}$ and D). The species $\mathrm{ML}_{2} \mathrm{H}_{2}, \mathrm{ML}_{2} \mathrm{H}$ and $\mathrm{ML}_{2}$ are formed in the $\mathrm{pH}$ range 5.0-9.0. In this context, Equilibria 2 and 3 represent the successive deprotonation of $\mathrm{ML}_{2} \mathrm{H}_{2}$ to $\mathrm{ML}_{2} \mathrm{H}$ and $\mathrm{ML}_{2} \mathrm{H}$ to $\mathrm{ML}_{2}$. Figures $2 \mathrm{~B}$ and $\mathrm{C}$ show the formation of $\mathrm{Cu}(\mathrm{II})-$ and $\mathrm{Ni}(\mathrm{II})-\mathrm{Asp}$ complexes. $\mathrm{ML}_{2}$ 
species are formed to an extent of $90-95 \%$. ML is formed by the deprotonation of MLH species (Equilibrium 6). $\mathrm{ML}_{2}$ can also be formed by Equilibrium 7. The stabilities of the complexes follow Irving-Williams order, i.e. $\mathrm{Co}$ (II) $>\mathrm{Ni}$ (II) $>\mathrm{Cu}$ (II) $<\mathrm{Zn}$ (II). Based on the above equilibria the possible structures of the binary complexes of Asp are given in Figure 3.

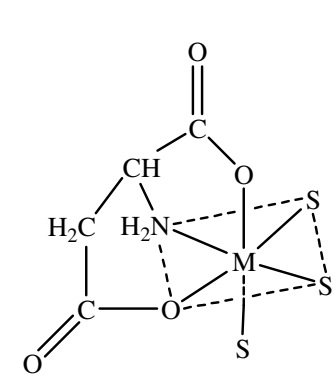

ML

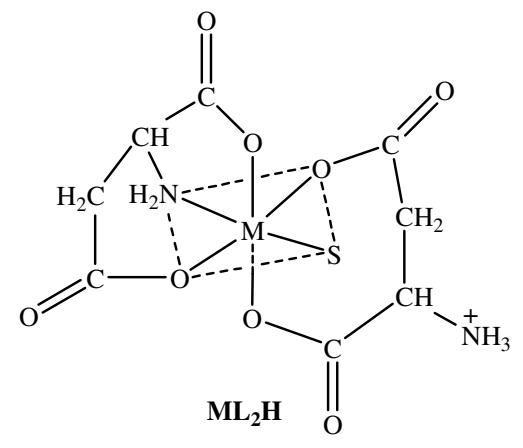

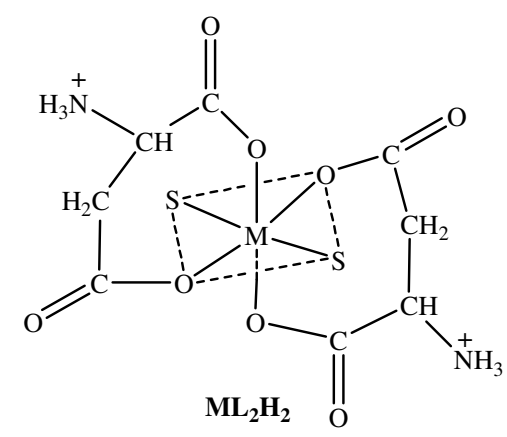

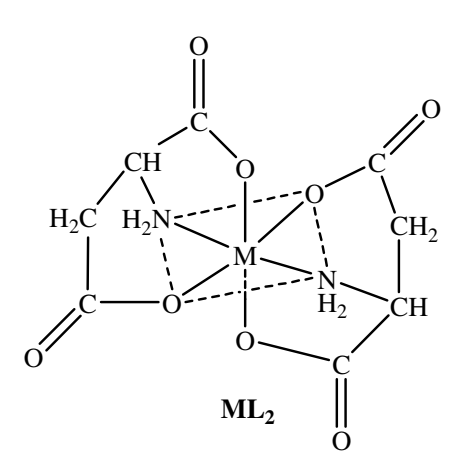

Figure 3. Structures of binary complexes of Asp.

\section{CONCLUSIONS}

The models for the binary species contained $\mathrm{ML}_{2} \mathrm{H}_{2}, \mathrm{ML}_{2} \mathrm{H}$ and $\mathrm{ML}_{2}$ for $\mathrm{Co}$ (II) and $\mathrm{Zn}$ (II), ML, $\mathrm{ML}_{2} \mathrm{H}_{2}$ and $\mathrm{ML}_{2}$ for $\mathrm{Ni}(\mathrm{II})$ and $\mathrm{Cu}(\mathrm{II})$ in $\mathrm{AN}$ - and EG-water mixtures. The stability constants increased linearly with decreasing dielectric constant of AN- and EG-water mixtures. This trend indicates the dominance of electrostatic forces over non-electrostatic forces in the speciation of binary complexes. The effect of systematic errors in the influential parameters shows that the errors in the concentrations of alkali, mineral acid, ligand and metal affect the stability constants in the order alkali $>$ acid $>$ ligand $>$ metal.

\section{ACKNOWLEDGEMENTS}

The first author (NVK) thanks the University Grants Commission, Government of India, New Delhi, India for financial support under Faculty Development Programme. 


\section{REFERENCES}

1. Rao, P.S.; Srikanth, B.; Rao, V.S.; Sastry, C.K.; Rao, G.N. E-J. Chem. 2009, 6, 561.

2. Latha, M.P.; Rao, V.M.; Rao, T.S.; Rao, G.N. Acta Chim. Slov. 2007, 54, 160.

3. Sharma, A.; Gupta, K.D.; Saxena, K.K. J. Indian Council Chemists. 2002, 19, 43.

4. Taf, R.W. Prog. Phys. Org. Chem. 1983, 14, 247.

5. Hens, J. Structural Effects on Equilibria in Organic Chemistry, Wiley: New York; 1975.

6. Tapiero, H.; Mathe, G.; Couvreur, P.; Tew, K.D. Biomed Pharmacother. 2002, 56, 446.

7. Fitsamakis, A. V.; Michael, A. Toxicol. Appl. Pharm. 2004, 204, 343.

8. Hu, L.T.; Mobley, H.L. Immunology 1990, 58, 992.

9. Mulrooney, S.B.; Hausinger, R.P. Microbiol. Rev. 2003, 27, 239.

10. Dunn, B.E.; Champbell, G.P.; Perz-Perz, G.I.; Blaser, M.J. J. Biol. Chem. 1990, 265, 9464.

11. Walker, W.R.; Reeves, R.R.; Brosanan, R.; Coleman, G. Bioinorg. Chem. 1977, 7, 271.

12. Holm, R.H.; Kennepohl, P.; Solomon, E.J. Chem. Rev. 1996, 96, 2239.

13. Vallee, B.L. Biofactors 1988, 1, 31.

14. Das, K.; Das, A.K.; Kundu, K.K. Electrochim. Acta 1984, 261, 471.

15. Feakins, D. Physico-chemical Processes in Mineral Solvents, Franks, F. (Ed.), Heinmann Educational Book Ltd.: London; 1967.

16. Wells, C.F.J. Chem. Soc. Faraday Trans I 1975, 71, 868.

17. Basu-Mullik, I.N.; Kundu, K.K. Can. J. Chem. 1980, 58, 79.

18. Devi, K.V.S.; Raju, B.R.; Rao, G.N. Acta Chim. Slov. 2010, 57, 398.

19. Rao, V.M.; Latha, M.P.; Rao, T.S.; Rao, G.N. J. Indian Chem. Soc. 2007, 84, 346.

20. Rao, G.N.; Murthy, V.L.S.N.J. Indian Chem. Soc. 2004, 81, 424.

21. Gran, G. Analyst 1952, 77, 661.

22. Gran, G. Anal. Chim. Acta 1988, 206, 111.

23. Padmaja, N.; Babu, M.S.; Rao, G.N.; Rao, R.S.; Ramana, K.V. Polyhedron 1990, 9, 2497.

24. Rao, G.N. Ph.D. Thesis, Andhra University, Visakhapatnam, India; 1989.

25. Gans, P.; Sabatini, A.; Vacca, A. Inorg. Chim. Acta 1976, 18, 237.

26. Latha, M.P.; Rao, V.M.; Rao, T.S.; Rao, G.N. Bull. Chem. Soc. Ethiop. 2007, 21, 363.

27. Born, M.Z. Phys. 1920, 1, 45.

28. Singh, A.K.; Manjula, D.J. Indian Chem. Soc. 2001, 71, 635.

29. Cordes, E.H. Pure Appl. Chem. 1978, 50, 617. 